\title{
APPLICATION OF GEOLOGICAL AND ELECTRICAL RESISTIVITY METHODS FOR GROUNDWATER STUDIES AT TATIKO, NORTH CENTRAL NIGERIA
}

\section{AWEDA ABDULWAHID KOLAWOLE, SHEHU IBRAHIM KAGARA, IGE OLUSEGUN OMONIYI, UMAR, MOHAMMED UMAR, DAVID JOSEPH BARDE}

(Received 24 January 2019; Revision Accepted 13 June 2019)

\begin{abstract}
The success probability of water wells constructed in crystalline rock terrains is largely dependent on the size, location and interconnectivity of the fractures present in them as well as the amount and nature of the material that may clog the fractures. Geological and geoelectrical studies were proposed and conducted at Tatiko to determine the structures in the underlying basement rocks and evaluate their groundwater potential. Geological study was used to delineate the structural control on groundwater availability while the geoelectrical study (Vertical Electrical Sounding) was used to investigate the properties of the subsurface materials and determine their potential to host sufficient quantity of groundwater.

Structural data were plotted on a rosset diagram and showed major structural control trending in the NW - SE direction. Quantitative interpretation of the geoelectric data indicates that the major fractures are within the weathered to competent basement indicating good hydraulic connection between the weathered and fresh basement. The fractures are deepest within the region that showed thicker weathering and are as shallow as 7 meters in other regions. Apparent resistivity of the fractures ranges between $100 \Omega \mathrm{m}$ and $1200 \Omega \mathrm{m}$ in most parts of the area with the highest values in the west. An integration of the result clearly showed that the NW and SW parts of the study area are the most favourable for drilling and further groundwater studies and drilling is recommended to a depth of $40 \mathrm{~m}$ to $50 \mathrm{~m}$.
\end{abstract}

KEYWORDS: Groundwater, Geoelectrical study, Fractures, Tatiko, Resistivity, Basement Complex.

\section{INTRODUCTION}

Apart from economic challenges, one of the major reasons for the low standard of living in sub-Saharan Africa, especially the rural regions, is the lack of access to safe water resources. In this region, crystalline basement rocks occupy $40 \%$ of the land area (Wright, 1985). These rocks are known for their poor groundwater potential and challenging groundwater exploration conditions due to the absence of primary porosity in them. The only aquifer is found to be in the weathered and fractured part of the crystalline rocks (Bereket, 2011). However, the yield of aquifers in crystalline rocks depends on the size and location of the fractures, interconnectivity of the fractures, amount and nature of the material that may clog the fractures and their recharge sources. Groundwater exploration in these rocks is essentially to detect these fracture properties. A combination of structural geological study and electrical resistivity method is a viable option to capture these properties.

The proper use of geophysical methods and related studies have made a major contribution in solving groundwater problems of the crystalline rock areas and the results have been widely reported (Al-Garni, 2009; Chikwelu and Udensi, 2013; Fadele et al., 2013; Adepelumi, 2013; Oladunjoye et al. 2013; Cassidy et al.

Aweda Abdulwahid Kolawole, Department of Geology and Mining, Ibrahim Badamasi Babangida University, Lapai,

PMB 11, Niger State, Nigeria.

Shehu Ibrahim Kagara, Department of Geology and Mining, Ibrahim Badamasi Babangida University, Lapai, PMB 11, Niger State, Nigeria.

Ige Olusegun Omoniyi, Department of Geology and Mineral Sciences, University of Ilorin, Nigeria.

Umar, Mohammed Umar, Department of Geology and Mining, Ibrahim Badamasi Babangida University, Lapai, PMB 11, Niger State, Nigeria.

David Joseph Barde Department of Geology and Mining, Ibrahim Badamasi Babangida University, Lapai, PMB 11, Niger State, Nigeria. 
2014; Ejepu and Olasehinde, 2014; Mohamaden et al, 2016, Aliyu et al. 2016; etc). In this study, hydrogeophysical (electrical resistivity) and structural geological studies are integrated to unravel the groundwater potential of Tatiko District, Northcentral Nigeria with the aim of upgrading drilling success in the area which is currently put at less than $30 \%$.

\section{THE STUDY AREA}

The study area, Tatiko, is located off the Minna-Lapai road, which is about $10 \mathrm{~km}$ from Minna, Northcentral Nigeria and lies between latitude $9^{0} 24^{\prime} .30^{\prime \prime} \mathrm{N}$ to $9^{0} 25^{\prime} .30^{\prime} \mathrm{N}$ and longitude $6^{0} 35^{\prime} .00^{\prime \prime} \mathrm{E}$ to $6^{0} 36^{\prime} .00^{\prime \prime} \mathrm{E}$ with approximate areal extent of $1 \mathrm{~km}^{2}$ (Figure 1). This area falls within the basement complex of Northcentral Nigeria.
A description of regional geology of the basement complex has been attempted by various authors including Oyawoye (1972), McCurry (1973, 1976), Black (1980). The complex is part of the Pan-African mobile belt and lies within the West African and Congo Craton (Black, 1980). The Pan-African Orogeny was said to have affected the Nigerian Basement and the rocks are believed to be the result of at least four major orogenic cycles of deformation, metamorphism and remobilization which corresponds to the Liberian (2,700Ma), Eburnean (2,000Ma), Kibaran (1,100Ma) and the Pan-African Cycles (600Ma). The Mesozoic younger granites of the Jos Plateau are believed to have intruded the Basement Complex and the complex is overlain unconformably by the cretaceous sediments (Figure2).

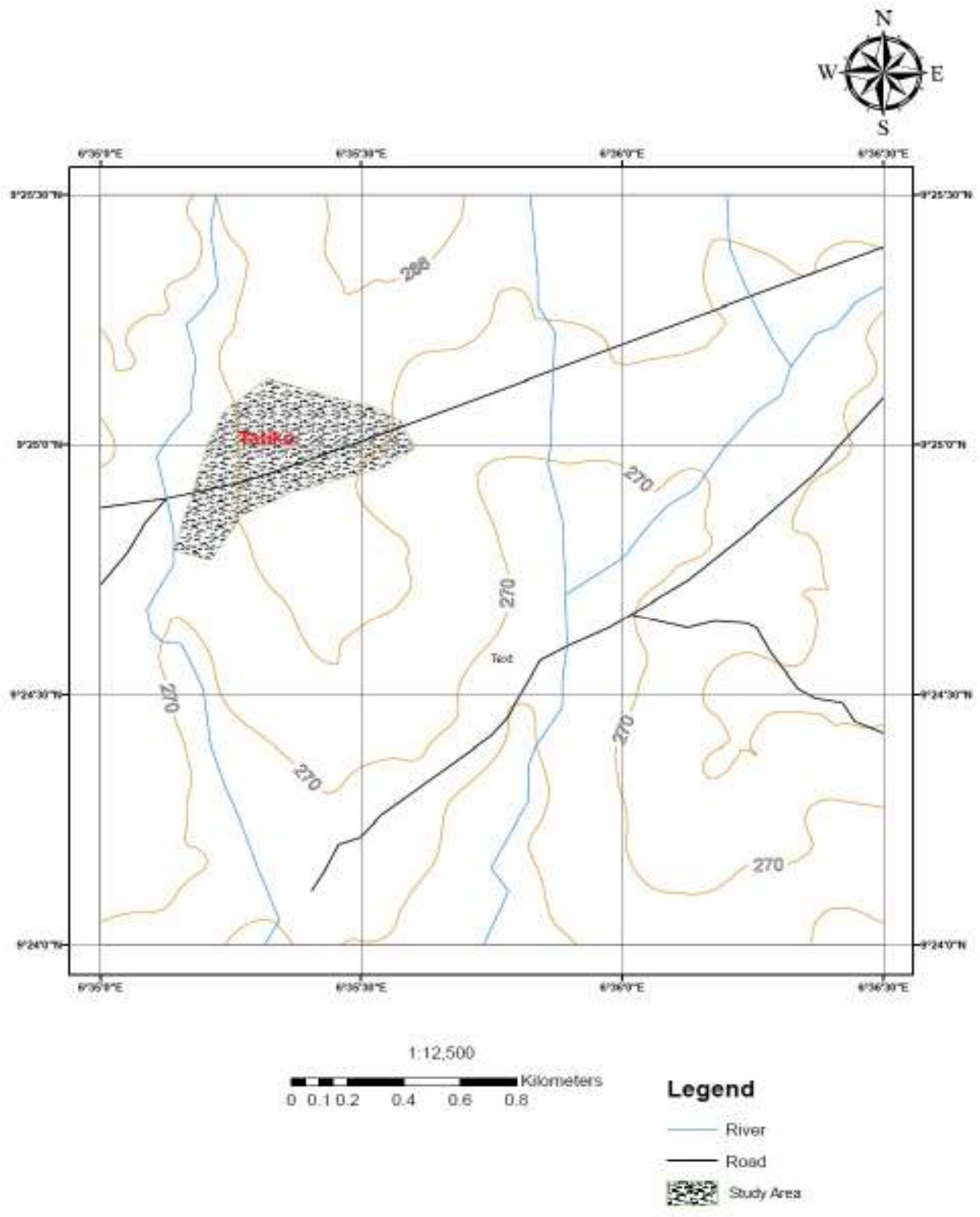

Figure 1. Location Map of the Study Area 


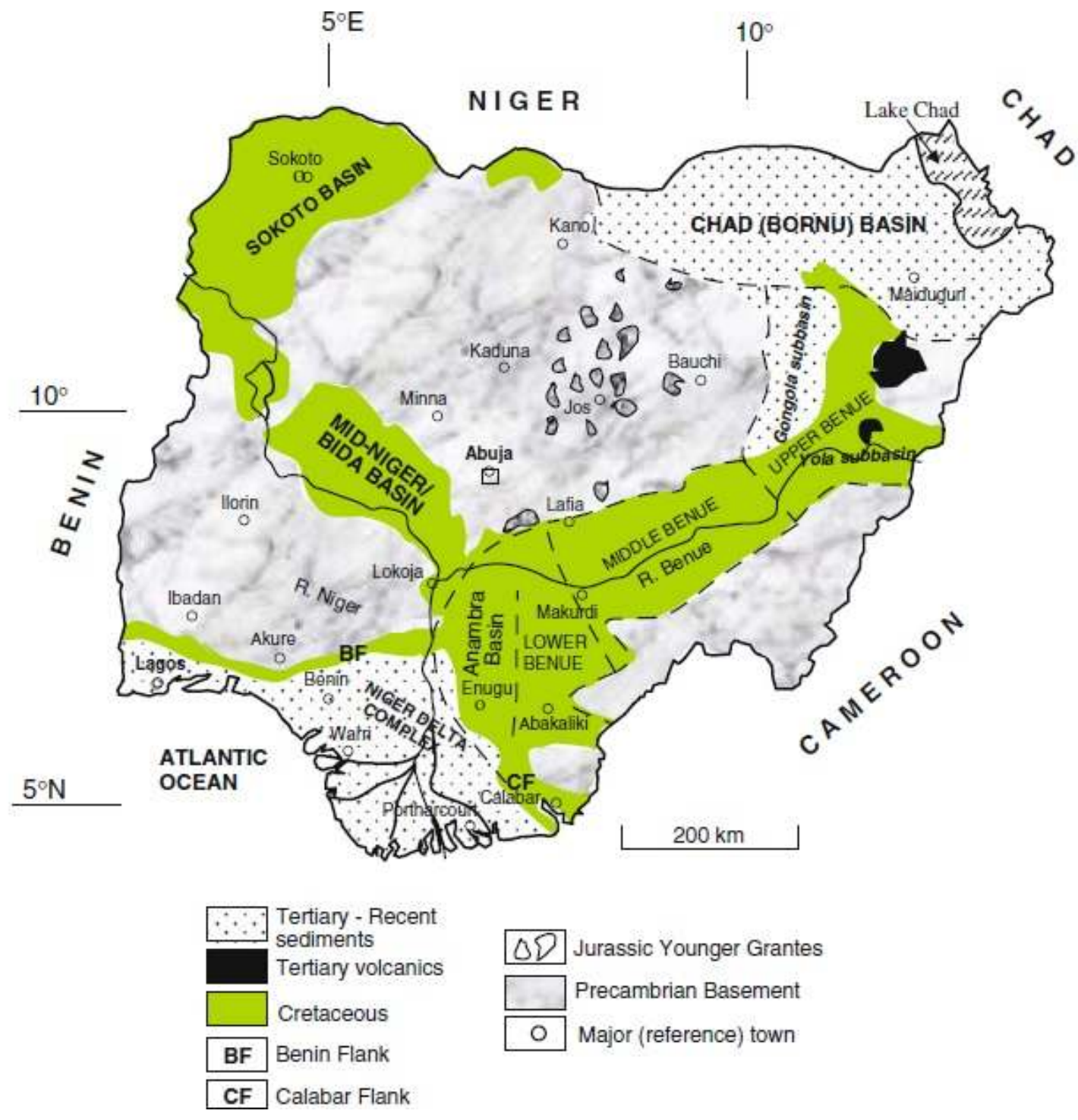

Figure 2. Geological Map of Nigeria (After Obaje, 2009).

\section{METHODOLOGY}

\section{Geological Studies}

Geological mapping was carried out to understand the major structural features in the study area. Structures such as joints and faults were identified and their orientations noted. The data obtained was plotted on a rosette diagram in other to identify the trends of the structural control on groundwater in the area.

\section{Geophysical Measurement}

Three geophysical traverses were designed to cut across the identified structural trends. Five geoelectrical soundings, using the Vertical Electrical Sounding (VES), were conducted on each traverse to a maximum $A B / 2$ spread of 100 meters. A total of 15 VES were conducted in the study.
The VES technique is considered the best technique for groundwater exploration (Al-Garni, 2009). It measures the variation in apparent resistivity of an assumed horizontally layered earth material around a stationary centre point of the configuration (Aliyu et al., 2016). The sounding is conducted by expanding the electrode separation at intervals about, a fixed point considered as the centre of the array, until the desired electrode spread $(A B / 2)$ is reached.

The apparent resistivity data were interpreted using the IX1D and WINRESIST geophysical data inversion software (Figure 3) and used to produce fracture resistivity, depth, thickness and depth to basement maps. 

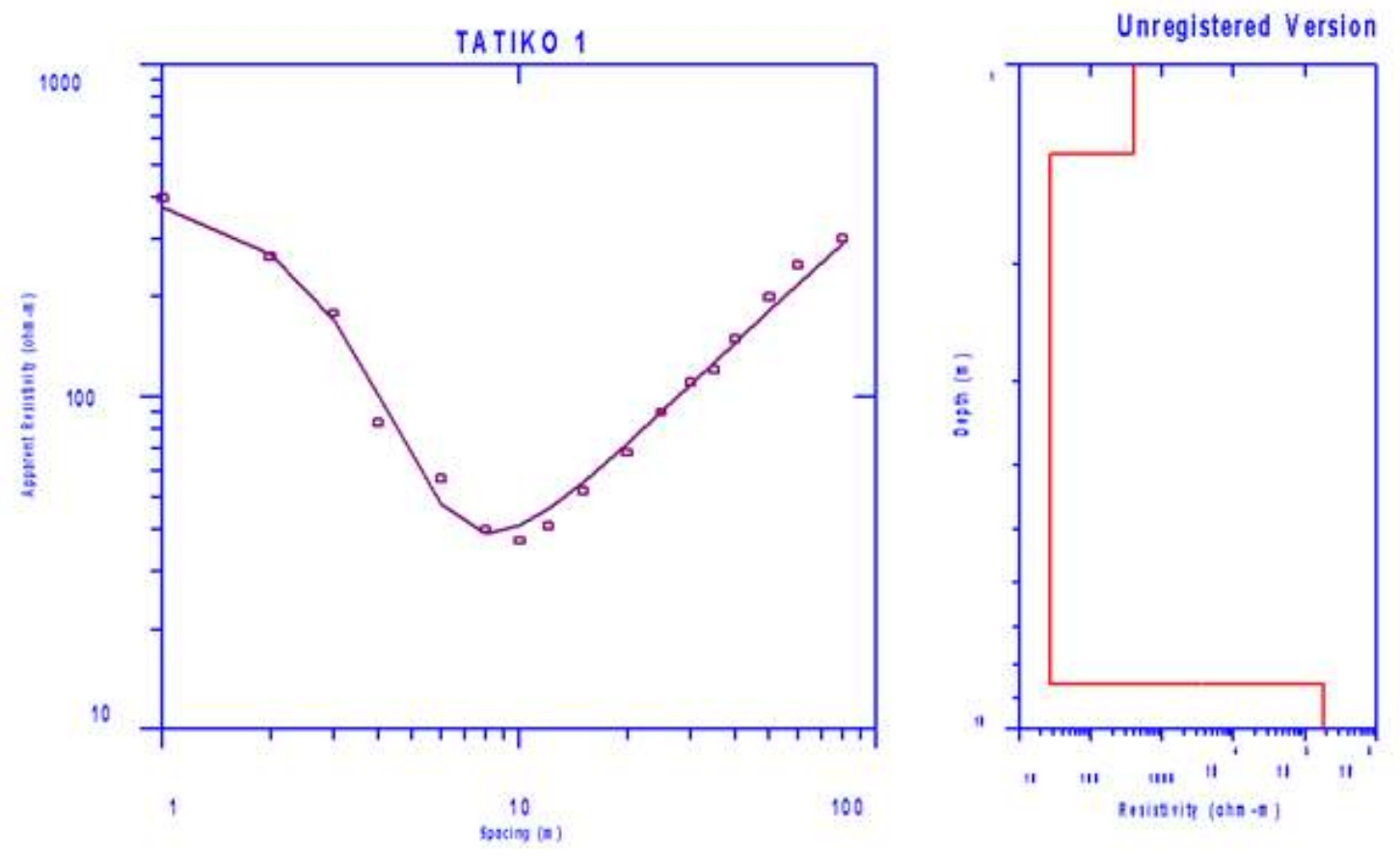

Figure 3: Apparent Resistivity Model Curve for one of the Sounding Points (VES 1)

\section{RESULTS}

Geological studies indicated that the study area is underlain by gneisses (Figure 4). The rocks show high level of deformation which is visible in the form of joints, fractures and realignment of minerals. The southern part of the area is made up of granitic rocks. The structures are majorly aligned in the NW - SE direction when plotted on the rosset diagram (Figure 5).

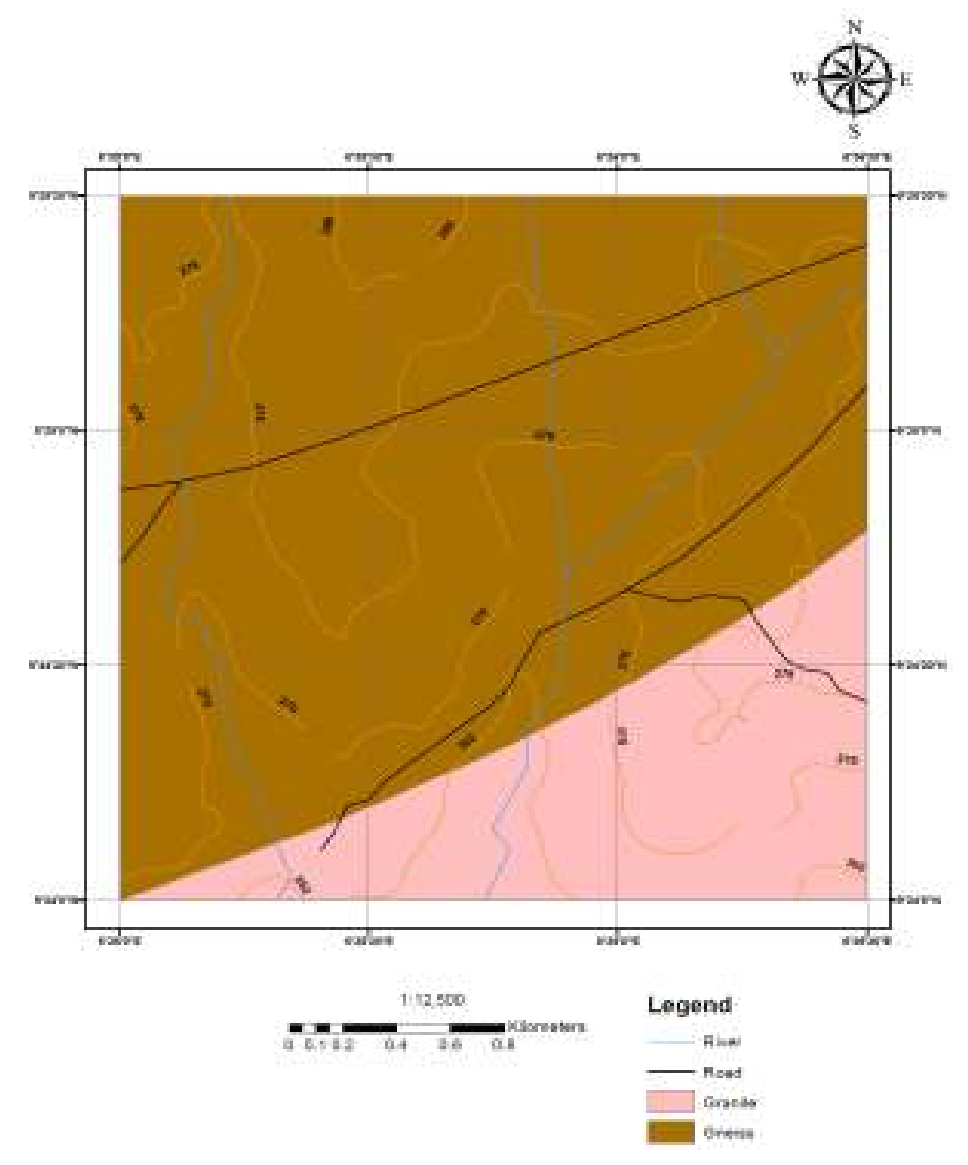

Fiaure 4. Geoloaical Man of the Studv Area 


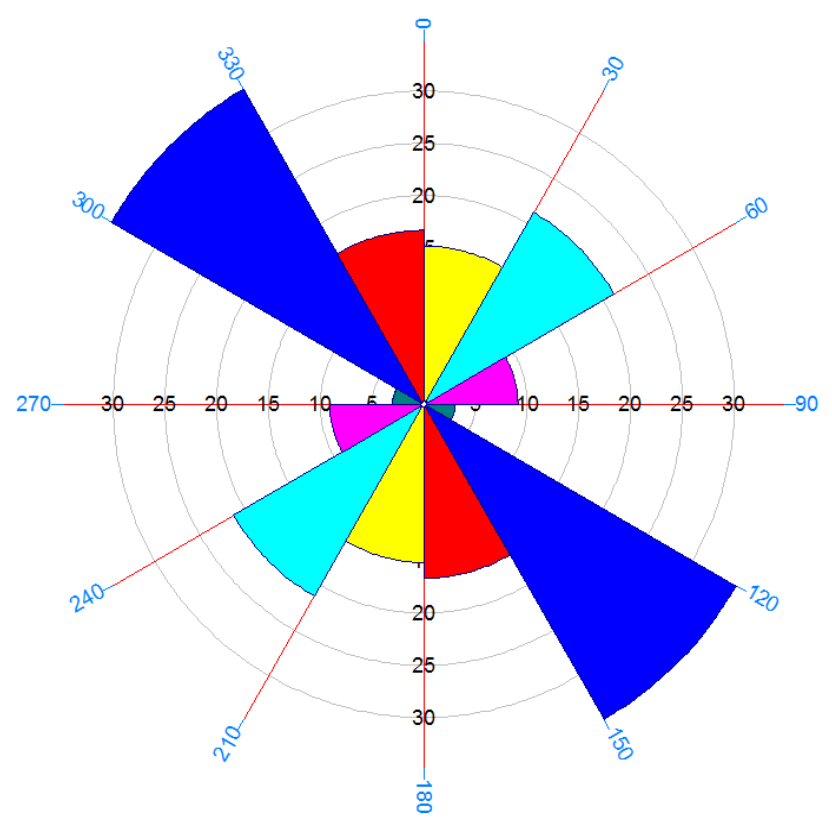

Figure 5. Structural Readings Plotted on a Rosset Diagram

The interpreted VES curves are confined to the H-type curve and all the graphs revealed only three (3) geoelectric layers with the exception of VES 4 which has 4 layers. VES data plotted as depth to basement map (Figure 6) indicates that the bedrock is at a depth of between 6 meters and 16 meters. The depth gets shallower to the east. The central region shows a depression which is steeper towards the NNE and SSW direction.

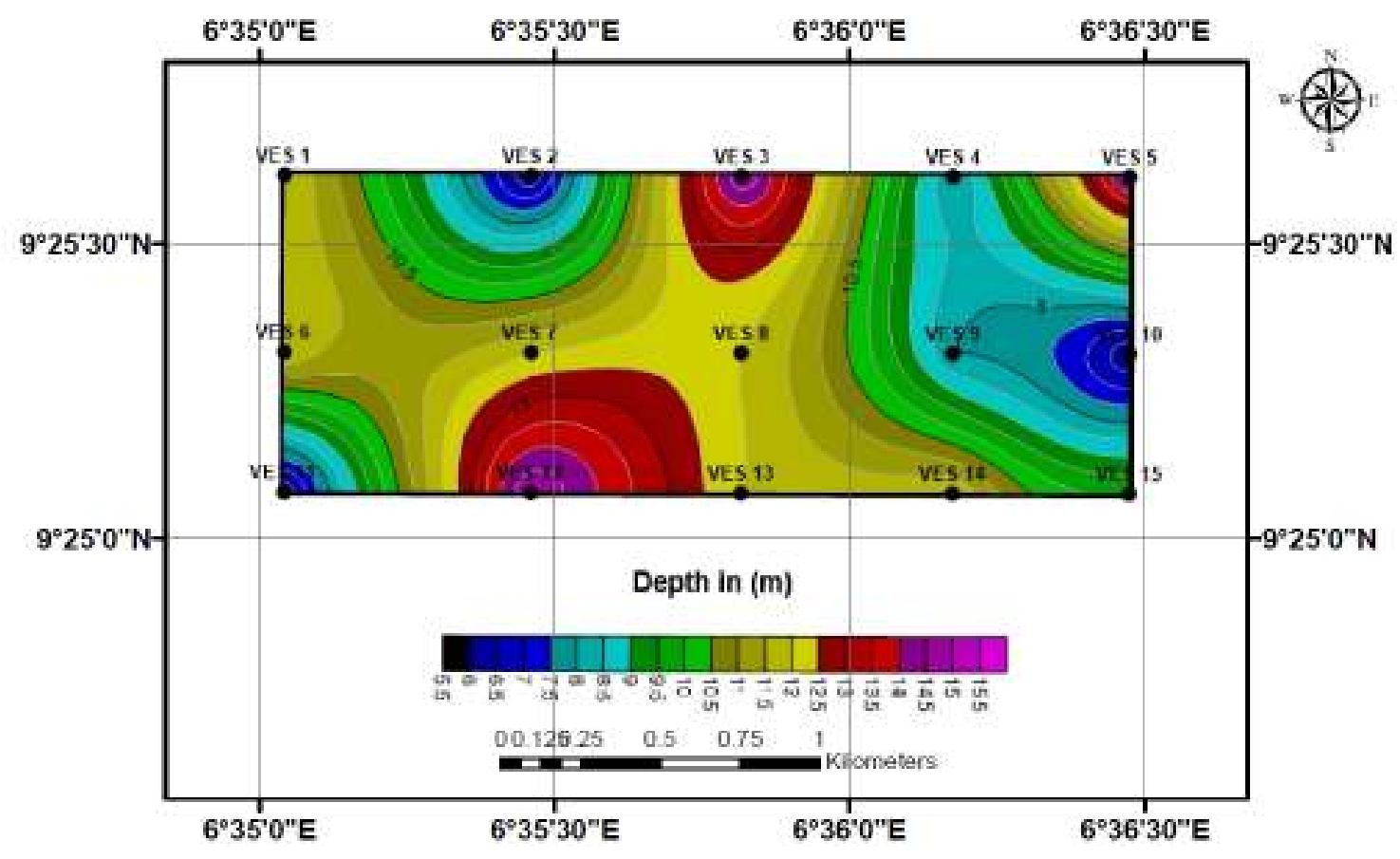

Figure 6. Depth to Basement Map

The fractures are as shallow as 7 meters in the SE part of the study area to a maximum depth of 24 meters at localized regions (Figure 7). The NNE and SSW have a fracture depth of between 14 meters 21 meters which seems to follow the trend obtained from the depth to basement map. 


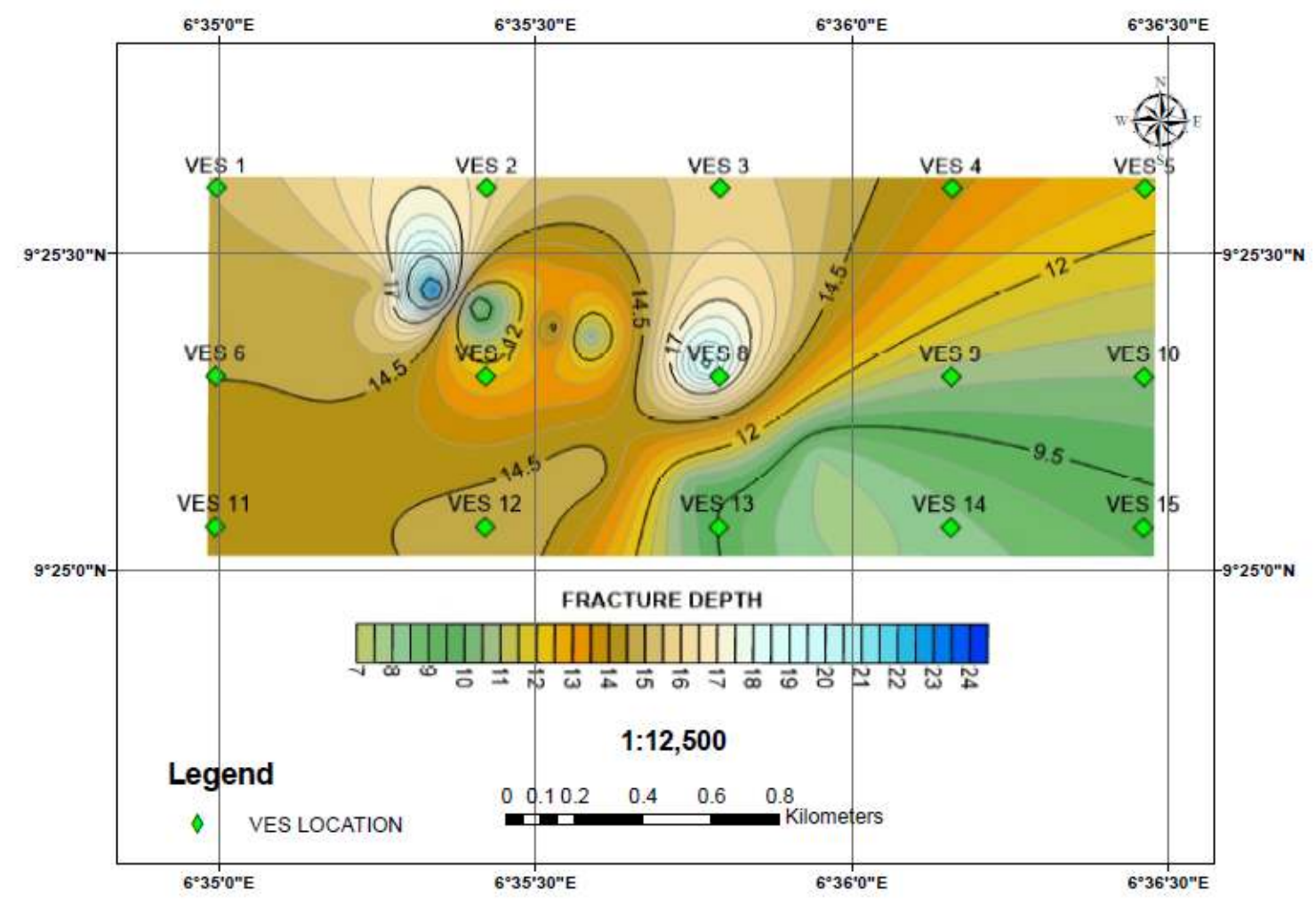

Figure 7. Fracture Depth Map

The fracture resistivities are as low as $100 \Omega \mathrm{m}$ in the eastern part of the area and between $600 \Omega m$ and $1200 \Omega m$ in most of the western part (Figure 8). Fracture thickness is between 5.5 meters and 15.5 meters in the NW and SW. The NE and SE have lower fracture thickness of between 2 meters and 7.5 meters (Figure 9).

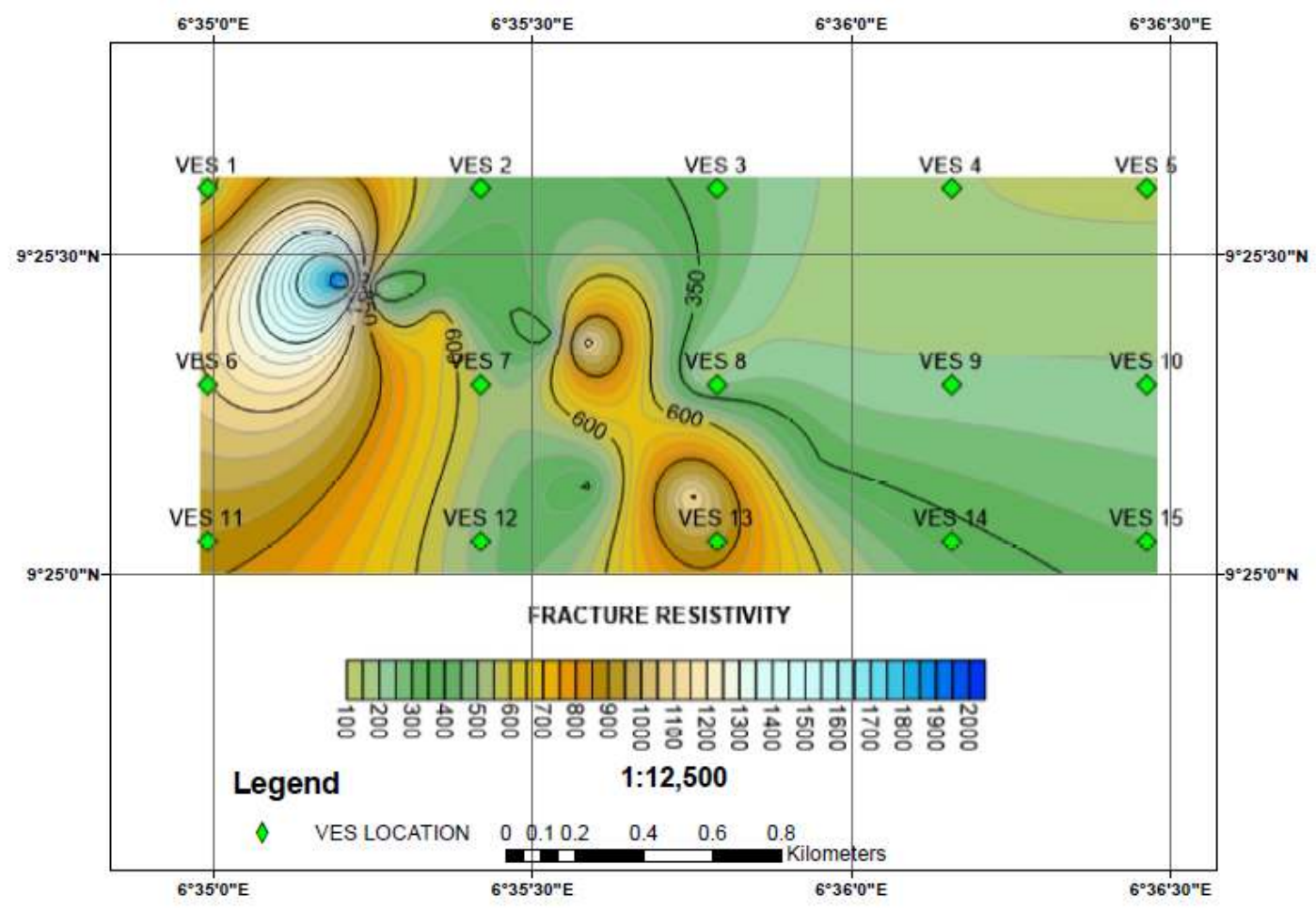

Figure 8. Fracture Resistivity Map 


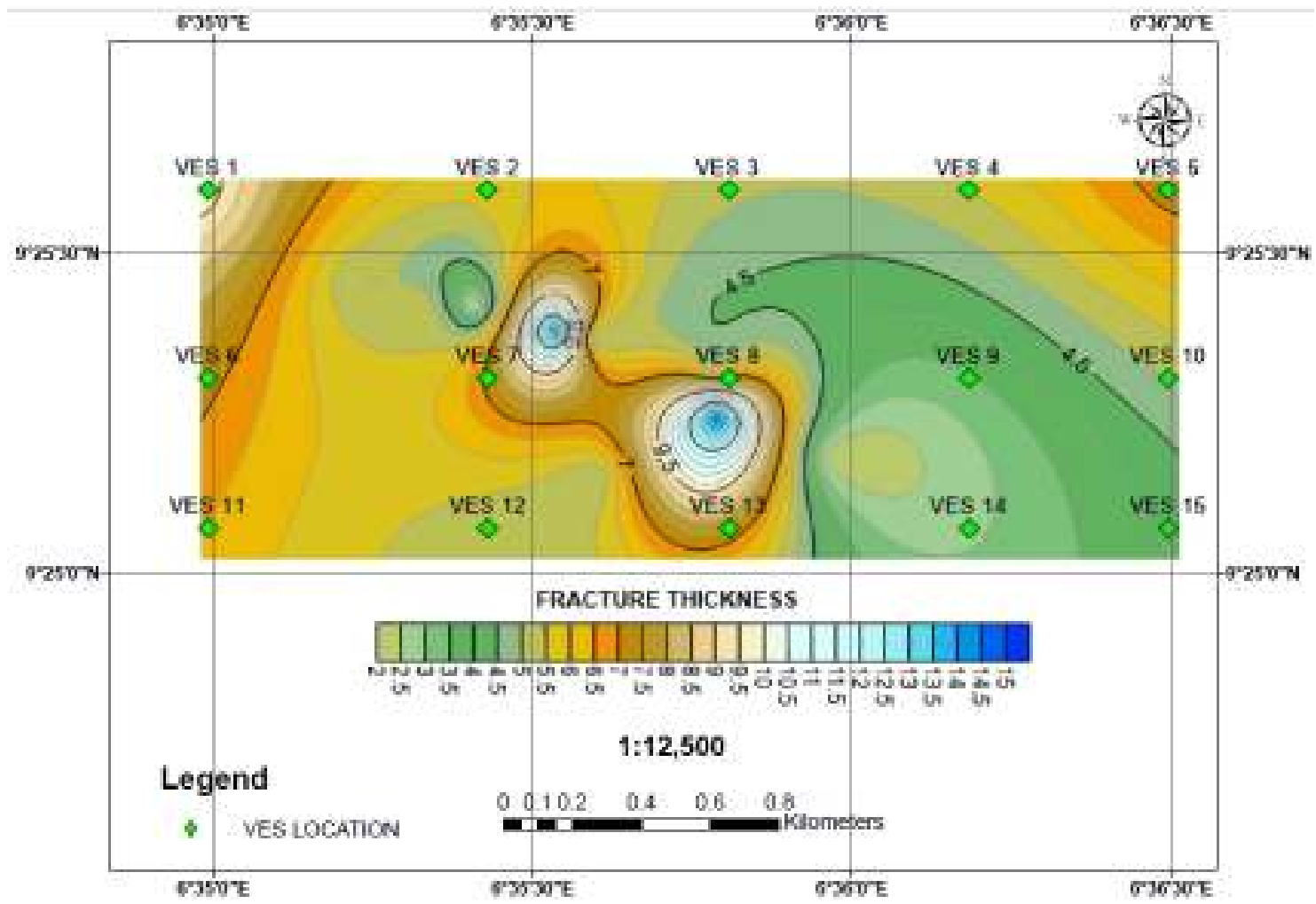

Figure 9. Fracture Thickness Map

\section{DISCUSSION}

In areas underlain by crystalline rocks, a combination of sufficiently thick weathering and high fracturing are the main targets for groundwater search activities. The major fractures in the study area are within the highly weathered and fresh basement. In this type of region, this connection between the weathered and fresh basement is responsible for groundwater recharge to aquifers. Most of the study area showed fracture resistivity of as low as $100 \Omega \mathrm{m}$ to as high as $1200 \Omega \mathrm{m}$. The areas with this high resistivity cannot be ruled out during exploration so long as there is evidence of sufficient weathering and multiple fracturing. The NE and SE parts generally demonstrate features which are not consistent with search targets during groundwater exploration. The very shallow depth of the bedrock (5.5meters to 10.5 meters) as well as low fracture depth and thickness are not likely to produce sufficient groundwater to hand-dug wells. On the other hand, the NW and SW parts show high prospects for groundwater availability. Interpretation of the depth to basement and fracture depth maps show strong indication of groundwater flow from the SE towards the central parts of the area, and ultimately to the NW and SW. These regions therefore shows potential occurrence of viable groundwater. Viable drilling at depth of between 40 meters and 50 meters is recommended.

\section{CONCLUSION}

The difficulty encountered during groundwater exploration in basement terrains can be reduced by local geological study and quantitatively interpreting the VES data and usina them to denerate various models.
Geological and geoelectrical studies were conducted in Tatiko to locate the geological structures and evaluate their groundwater potential. The geological study showed the dominant structures trending in the NW SE direction. Interpretation of the VES data alongside geological data clearly showed that the NW and SW parts of the study area are most suitable for water well drilling and further detailed studies. Drilling is recommended to depths of 40 meters to 50 meters in this area.

\section{REFERENCES}

Adepelumi, A. A., Akinmade, O. B. and Fayemi, O., 2013. Evaluation of groundwater potential of Baikin Ondo State Nigeria using resistivity and magnetic techniques: A case study. Universal Journal of Geoscience, 1, (2): 37-45.

Al-Garni, M. A., 2009. Geophysical Investigations for Groundwater in a Complex Subsurface Terrain, Wadi Fatima, KSA: A Case History. Jordan Journal of Civil Engineering, 3, (2): 118-136.

Aliyu, M., Ojo, A. O. and Olorunfemi, M. O., 2016. Geoelectrical and Hydrogeochemical Characterisation of the Basement Complex Aquifers in the Area around the Abuja City Centre, Nigeria. Ife Journal of Science, 18, (2): 321-330.

Bereket, M. D., 2011. Integration of geophysical methods for groundwater exploration in hard rock areas: Annlication to Alla Vallev. Eritrea. 
AWEDA ABDULWAHID KOLAWOLE, SHEHU IBRAHIM KAGARA, IGE OLUSEGUN OMONIYI, UMAR. MOHAMMED UMAR. DAVID JOSEPH BARDE

NE Africa. Unpublished PhD thesis, McCurry, P., 1973. Geology of Degree Sheet 21, Zaria, Loughborough University, 266. Nigeria. Overseas Geol Mineral Res, 45:1-30.

Black, R. 1980. Precambrian of West Africa. Episodes, 4: 3-8.

Cassidy, R., Comte, J., Nitsche, J., Wilson, C., Flynn, R., and Ofterdinger, U., 2014. Combining multi-scale geophysical techniques for robust hydrostructural characterisation in catchments underlain by hard rock in post-glacial regions. Journal of Hydrology, 517: 715-731.

Chikwelu, E. E. and Udensi, E. E., 2013. Geoelectric determination of the groundwater potential of parts of Pompo Village, Minna, Nigeria. International Journal of scientific research and management, 1, (3): 122-132.

Ejepu, S. J. and Olasehinde, P. I., 2014. Groundwater potential evaluation in the crystalline basement of Gidan Kwano Campus, Federal University of Technology, Minna, North-Central Nigeria using geoelectric methods. Universal Journal of Geoscience, 2, (4): 123-132.

Fadele, S. I., Sule, P. O. and Dewu, B. B. M., 2013. The use of vertical electrical sounding

for groundwater exploration around Nigerian College of Aviation Technology, Zaria, Kaduna State, Nigeria. The Pacific Journal of Science and Technology, 14 (1): 549-555.

McCurry, P., 1976. The geology of the Precambrian to Lower Palaeozoic Rocks of Northern Nigeria - A Review. In: Kogbe CA (ed) Geology of Nigeria. Elizabethan Publishers, Lagos, 15-39.

Mohamaden, M I I., Hamouda, A.Z. and Mansour. S. 2016. Application of electrical resistivity method for groundwater exploration at the Moghra area, Western Desert, Egypt. Egyptian Journal of Aquatic Research, 42, (3), 261-268.

Obaje, N. G., 2009. Geology and mineral resources of Nigeria. Springer-Verlag Berlin Heidelberg, 221.

Oladunjoye, M., Adabanija, M., and Adeboye, O., 2013. Groundwater Prospecting and Exploration in a Low Potential Hard Rock Aquifer: Case Study from Ogbomoso North, Southwestern Nigeria. Journal of Environment and Earth Science, 3 (14), $84-102$.

Oyawoye, M.O. 1972. The basement complex of Nigeria. In: Dessauvagie TFJ, Whiteman AJ (eds) African geology. Ibadan University Press, 66-102

Wright, J. B. 1985. Geology and mineral resources of West Africa. George Allen and Unwin, London, $187 \mathrm{pp}$. 